of the letters, 84, 131-142 [in Ukrainian].

Shepel Yu. O., Panchenko O. I. (2016). Text as an object of linguistics and the basis of communication. Linguistics. Linguoculturology: A Collection of Sciences. Dr. Philol. of Sciences, academician of the Academy of Sciences of Ukraine, prof. Yu.O. Shepel. Oles Honchar Dnipropetrovsk National University. Retrieved from: http://lingvodnu.com.ua/arxiv-nomeriv/lingvistika-lingvokulturologiya-tom-9-2016/tekst-yak-obyektlingvistiki-j-osnova-spilkuvannya/ [in Ukrainian].

УДК 002.1:316.77]:[005:027

Ковальчук Наталія Володимирівна, здобувач кафедри культурології та інформаційних комунікацій Національної академії керівних кадрів культури і мистецтв natalisem@ukr.net ORCID 0000-0002-6364-7499

\title{
ДОКУМЕНТНІ КОМУНІКАЦІЇ В УПРАВЛІННІ БІБЛІОТЕКОЮ
}

Мета роботи - проаналізувати значення документних комунікацій в управлінні бібліотекою $\check{u}$ визначити напрями їх удосконалення. Методологія дослідження полягає у використанні соціокомунікаційного, системного й інформаційного підходів, щяо дозволило проаналізувати значення документних комунікацій в управлінні бібліотекою й розглянути їх як систему, щзо має свою мету, документно-інформаџійні ресурси, внутрішньоорганізаційну комунікацію, комунікацію із зовнішнім середовищем і зворотний зв'язок. Наукова новизна роботи полягає в розширенні уявлень про функиіонуваннядокументнихкомунікаційвуправліннібібліотекоюякиілісноїдокументно-інформаційної системи, з урахуванням специфіки діяльності бібліотеки. Висновки. Комунікація, яка побудована на обміні між двома або більше учасниками комунікаційного процесу, у результаті створення, зберігання u розповсюдження документів $і$ є документною комунікацією. Отже, документна комунікація в управлінні бібліотекою - це система, щзо охоплює документообіг установи, засоби їх доведення до користувача, власне бібліотеки як документно-інформачійні інституиії, зокрема керівники та певні працівники як учасники комунікаційного процесу (комунікант $\rightarrow$ реципієнт), $і$ зв'язок, який забезпечує прочес передачі інформації у зворотному напрямі (реципієнт $\rightarrow$ комунікант). Водночас удосконалення ичх процесів сприятиме формуванню якісного внутрішнього йзовнішнього документно-комунікаційного середовища, необхідного для реалізаиї стратегічних напрямів розвитку бібліотеки.

Ключові слова: документні комунікачії, комунікаційний процес, управління бібліотекою, комунікаиійне середовище.

Ковальчук Наталия Владимировна, соискатель кафедры культурологии и информационных коммуникаций Национальной академии руководящих кадров культуры и искусств

\section{ДОКУМЕНТНЫЕ КОММУНИКАЦИИ В УПРАВЛЕНИИ БИБЛИОТЕКОЙ}

Цель работы - проанализировать значение документных коммуникаций в управлении библиотекой и определить направления их усовершенствования. Методология исследования заключается в использовании социокоммуникаиионного, системного и информационного подходов, что позволило проанализировать значение документных коммуникаций в управлении библиотекой и рассмотреть их как систему, которая имеет свою цель, документо-информационные ресурсы, внутриорганизационную 
коммуникацию, коммуникаиию с внешней средой и обратную связь. Научная новизна работы заключаетсяврасширениипредставленийо функиионированиидокументныхкоммуникацийвуправлении библиотекой как иелостной документо-информационной системы, с учётом спеиифики деятельности библиотеки. Выводы. Коммуникация, построенная на обмене документами между двумя или более участниками коммуникаиионного процесса, в связи с созданием, хранением и распространением документов и является документной коммуникаиией. Таким образом, документная коммуникаиия 8 управлении библиотекой - это система, охватывающая документооборот учреждения, средства их доведения до пользователя, собственно библиотеки как документо-информационные институты, в том числе руководители и некоторые работники как участники коммуникационного процесса (коммуникант $\rightarrow$ речипиент), и связь, которая обеспечивает процесс передачи сообщения в обратном направлении (рещипиент $\rightarrow$ коммуникант). В то же время совершенствование этих процессов будет способствовать формированию качественной документо-коммуникационной среды, необходимой для реализации стратегических направлений развития библиотеки.

Ключевые слова: документные коммуникации, коммуникационный процесс, управление библиотекой, коммуникаиионная среда.

Kovalchuk Nataliya,

PhD-candidate of the Department of Cultural Studies and Informational Communications, National Academy of Culture and Arts Management

\section{DOCUMENT COMMUNICATIONS IN THE LIBRARY MANAGEMENT}

Purpose of Article. The goals of the article are to analyze the significance of the document communications in library management and to determine the ways of their improvement. Methodology. The methodology of the research consists of the socio-communication, system and information approaches, which have allowed us to study the importance of document communications in library management and consider them as a system with its purpose, document-information resources, internal organizational communication, communication with the external environment and feedback. Scientific Novelty. The scientific novelty of the research is to expand the understanding of the functioning of document communications in the management of the library as a total document-information system following their specific activities. Conclusions. The document communication is the communication based on the exchange among two or more participants of the communication process by the creation, saving, and dissemination of documents. Therefore, document communication in library management is a system that unites the documentations of the institutions and the means of its circulation. Thus, the library is the documentary information institution, which includes managers and employees, who are the participants of the communication process (communicator $\rightarrow$ recipient), and communication, which provides the process of transmitting information backward (recipient $\rightarrow$ communicator). At the same time, the improvement of these processes will contribute to the formation of a high-quality internal and external document-communication environment, which is essential for the implementation of strategic directions of the library development.

Key words: document communication, communication process, library management, communication environment.

Актуальність теми дослідження. У період активного реформування в країні суттєво змінюється місія бібліотеки як важливого інформаційно-комунікаційного центру. Зростання інформаційно-комунікаційних потреб сучасних користувачів поряд із збільшенням об'ємів інформаційних ресурсів актуалізує проблему організації діяльності бібліотеки, яка посилена наявною конкуренцією. Це потребує підвищення якості управління бібліо- текою, а саме: визначення іiі місії; установлення довготривалих цілей і короткострокових завдань; виявлення основної групи користувачів і наявних та очікуваних їхніх потреб; створення тотожних послуг i їх надання на максимально якісному рівні, пошуку шляхів удосконалення й засобів функціонування й організації інформаційно-комунікаційних процесів. Саме одним із важливих складових будь-якого професійного спілкування, зокре- 
ма управління $є$ документна комунікація, яка опосередкована документом i грунтується на обміні документами між двома чи більше людьми. Тому важливого значення набувають саме особливості ㄲï функціонування як такі, що поєднують у єдине ціле комунікаційну взаємодію між зовнішнім і внутрішнім середовищем бібліотеки.

Аналіз досліджень і публікацій. Питання теорії соціальних комунікацій як цілісної системи в іiі загальних і специфічних виявах проаналізовано в працях В. М. Бебика, В. В. Добровольської, І. М. Ломачинської, Н. В. Мурейко, Ю. І. Палехи, В. В. Різуна та ін. Теоретичні засади здійснення документнокомунікаційних процесів у межах бібліотек як соціальних інститутів в умовах інформаційних комунікацій досліджували М. В. Вилегжаніна, В. М. Горовий, Т. Ю. Гранчак, Т. В. Добко, О. М. Збанацька, В. О. Ільганаєва, Н. М. Кушнаренко, М. С. Слободяник, А. А. Соляник, Г. М. Швецова-Водка, Г. В. Шемаєва та ін.

Виклад основного матеріалу. В умовах інформатизації суспільства особливого значення набуває формування нових можливостей чіткої організації інформації в контексті документаційного забезпечення управління бібліотекою. Це пов'язано з тим, що саме управлінська інформація й ефективна комунікація як організаційний процес $\epsilon$ важливим чинником у діяльності бібліотеки та визначає ефективність iї функціонування. Водночас вони є засобом соціально-професійної комунікації та поширення знань, які сприяють виробленню інноваційної стратегії розвитку бібліотеки.

Соціальні комунікації дослідники вивчають як сукупність процесів і структур, що забезпечують цілеспрямований обіг соціальної інформації й знань у суспільстві. Так, на думку В. В. Різуна «система соціальних комунікацій» - це «система суспільної взаємодії, яка вміщує визначені шляхи, способи, засоби, принципи встановлення контактів на основі професійної технологічної діяльності, що спрямована на розробку, впровадження, організацію, удосконалення, модернізацію відносин у суспільстві, які складаються між різними соціальними інститутами де, з одного боку, у ролі ініціаторів спілкування най- частіше виступають соціальнокомунікаційні інститути, служби, а $з$ іншого - організовані спільноти (соціум, соціальні групи) як повноправні учасники соціальної взаємодії». Водночас у праці В. В. Різун зазначає, що «соціальна комунікація» - це спілкування, обумовлене ситуацією та соціально-психологічними особливостями комунікаторів процесом, що передбачає встановлення та підтримку контактів між членами певної соціальної групи. Така комунікація відбувається на основі професійного чи будь-якого іншого об'єднання учасників комунікації [10].

В. О. Ільганаєва наголошує на доцільності інтегрування різних підходів у дослідженні бібліотеки як соціального інституту, що $є$ водночас складовою інформаційного середовища та носієм інформаційної культури. Крім того, дослідниця відзначає, що «... сукупність умов матеріально-речових, субстанційнозмістових, технологічних, організаційних, у яких здійснюється комунікаційна взаємодія i здійснюється комунікаційний процес» [12].

Як зазначає В. В. Добровольська, що комунікаційне середовище «складається 3 двох основних складових - інфраструктурної та змістової». Зокрема, інфраструктурна складова - це документно-інформаційні інституції (музеї, бібліотеки, архіви, інформаційні агенціiі) та технічні засоби і канали комунікацій, що забезпечують реалізацію документального пошуку. Змістова складова, передусім, уміщує бібліографічну та документальну інформацію й знання, які є базовими для інформаційних працівників і споживачів [5, с. 28].

Нині активно розробляють теорію комунікації, проте недостатньо уваги приділено особливостям документних комунікацій у теоретичних і практичних аспектах, зокрема бібліотек.

Т. В. Добко під комунікаційним середовищем розуміє «...сучасне комунікаційне середовище, яке вміщує: інформаційні ресурси, інструментарії оброблення інформації і засоби комунікації» [4]. М. В. Вилегжаніна зазначає, що комунікаційне середовище дозволяє «... соціальним групам і структурам здійснювати передачу й обмін інформацією в комунікаційній взаємодії в просторі та часі» [1]. Таким чином, ми бачимо, що значну відмінність 
бібліотекам надає їі зовнішня комунікація зі своїми користувачами, зі своїм найближчим соціальним середовищем, спонсорами, партнерами бібліотеки, керівними структурами.

3 огляду на це плідною видається думка Г. М. Швецової-Водки про те, що в документі немає знань (емоцій, вольових дій), а є лише інформація, яка $€$ результатом комунікації, тобто тим, що одержує реципієнт, і поки він не одержить інформацію (не ознайомиться 3 документом), не можна сказати, що комунікація відбулася й що документ виконав своє призначення [13].

Разом 3 тим, Г. М. Швецова-Водка наводить таке визначення, що «документальна комунікація - це соціальна інформаційна комунікація, опосередкована документом, коли документ слугує за канал комунікації, тобто передачі інформації від комуніканта реципієнту, що здійснюється за допомогою документів». Автор зазначає, що комунікаційна функція полягає в тому, що документ є засобом комунікації й забезпечує один із видів соціальної комунікації (документну), яка без нього була б неможлива. Комунікаційна функція документа містить такі підфункції:

- $\quad$ документ є приймачем вираженої передавачем і призначеної для передавання інформації;

- документ $є$ сховищем переданої інформації, де вона зберігається і не зникає 3 перебігом часу;

- документ $\epsilon$ передавачем інформації, отриманої від комуніканта як джерела інформації до реципієнта;

- д документ $є$ безпосереднім джерелом інформації для реципієнта [14, с. 60].

Ю. Палеха й Н. Мурейко зазначають, що в процесі документально-інформаційної комунікації відтворюється складний, діалектичний взаємозв'язок між поняттями інформація й знання, тобто між відомостями, які становлять зміст повідомлення, що потребує декодування та може перетворитися на знання, котрі являють собою сукупність навичок, необхідних для діяльності в будь-якій сфері [9].

Також слушним $\epsilon$ визначення I. М. Ломачинської, яка вказує, що документальноінформаційна комунікація - це «комунікація, опосередкована документами в соціумі, що побудована на їхньому обміні між двома або більше споживачами інформації. На цій основі процес документально-інформаційної комунікації становить процес руху інформації в ланцюзі комунікант - комунікат (канал) - peципієнт (одержувач)». Таким чином, на думку автора для здійснення процесу комунікації в управлінні необхідні:

- $\quad$ комунікант або відправник, який передає інформацію та реципієнт, якому передається інформація;

- особисто саме повідомлення, тобто зафіксована інформація, у будь-якому вигляді, що призначена для передачі реципієнту;

- $\quad$ канал комунікації, тобто засіб, за допомогою якого передається інформація;

- $\quad$ зворотний зв' язок, який забезпечує процес передачі повідомлення у зворотному напрямі. а саме від реципієнта до комуніканта [8, c. 250].

Г. Гутброд та О. Беляков у своїй праці подають авторське бачення технології розбудови ефективних міжгрупових комунікаційних процесів, в основу яких покладено такий носій інформації як текст. Водночас у праці розглянуто і подано структурні схеми створення таких документів як: прес-реліз, офіційне повідомлення, доповідна записка, публічний звіт, діловий лист, проекти та плани подій. Також важливим $\epsilon$ те, що автори вперше запропонували конкретні стандарти розробки відповідної документації, що є найактуальнішою проблемою в сучасній українській культурі масових міжгрупових комунікацій [3].

Документальна комунікаційна система на думку А. А. Соляник, забезпечує цикл життєдіяльності документів, тобто їх виробництво, транспортування, збирання, зберігання й використання. Водночас, науковець зазначає, що документні комунікації відрізняються спрямованістю на різні види документальнокомунікаційних систем, серед яких: генеративні, транзитні, термінальні, форми та методи їх опрацювання й надання користувачеві $[11$, c. 8]. Тому, документна комунікація є однією з основних підсистем соціальної комунікації й побудована на обміні між двома або більше учасниками комунікаційного процесу документами. Вона виникла на певному етапі соціального прогресу людства і нині охоплює 
всі галузі суспільного життя [11, с. 5].

О. М. Збанацька наголошує, що документна комунікація - це процес руху в суспільстві документованої інформації, закріпленої на матеріальних носіях, яка породжує взаємодію інших видів соціальних комунікацій. Створювані документи відображають реалії сьогодення й водночас творять історію. Так реалізується одна з головних функцій документа - передавання інформації в просторі та часі $[6$, с. 26].

На думку В. М. Горового, особливістю комунікації є стабільність, достатня для функціонування надійність і можливість удосконалення й розвитку. А зниження надійності комунікацій, збій у їх роботі стає причиною і свідченням припинення розвитку системи, яку вони обслуговують. У складних системах комунікацій характерним є також те, що вони орієнтовані на передавання конкретного виду матеріального ресурсу всередині певної системи, необхідного для неї в їі функціонуванні, і не можуть використовуватись за межами призначення [2, с. 22].

Заслуговує на увагу твердження Н. М. Кушнаренко, що в основі документної комунікації лежить комунікаційний акт, у якому виділяють такі складові частини: той, хто передає документну інформацію, - комунікант - особа або організація, що генерують повідомлення (автор документа, документної інформації, повідомлення); той, кому призначена документна інформація, - реципієнт - це особа або група осіб, що приймають повідомлення (споживач документної інформації, читач, слухач, глядач); спосіб або канал передачі інформації - комунікант - це документ у формі книги, журналу, газети, фільму, дискети тощо; зміст переданої інформації, зафіксований на матеріальному носії; код - правила мови, якою зафіксовано повідомлення; контекст - у ньому повідомлення знаходить усю повноту свого змісту [7, с. 121].

Відмітимо, що каналом інформації в документній комунікації бібліотеки $є$ система якісного документообігу як матеріального носія, яка забезпечує документною інформацією внутрішніх і зовнішніх користувачів (реципієнтів) бібліотечної галузі. Інформативність документної комунікації $є$ односторонньою.
Вона знижується у зв'язку з тим, що інформація направлена в одну сторону, тобто від джерела до приймача, і щоб вона було ефективною, необхідний зворотний зв'язок, а саме, реакція приймача, яку повинно знати джерело, щоб при наступній передачі підвищити інформативність. Це сприятиме оперативному вирішенню питань таких:

- використання отриманої інформації про зовнішнє середовище для ефективної координації управлінської діяльності бібліотеки;

- $\quad$ збільшення часу для здійснення аналізу й прийняття управлінського рішення;

- забезпечення прямого та своєчасного доступу до управлінської документації;

- формування ефективності внутрішньої взаємодії між структурними підрозділами по технологічним каналам (прийом повідомлень тощо);

- створення інформаційних каналів для обміну інформацією між певними фахівцями та групами, й координація їх завдань i дій;

- використання нових інформаційних технологій системного аналізу та проектування оперативного управління на середніх і нижніх ланках управління;

- $\quad$ створення й аналіз документа як об'єктивної інформації, що є основним результатом інформаційно-комунікаційного процесу управлінського документування;

- забезпечення його оформлення відповідно до стандартів, за встановленою формою з необхідними реквізитами, або метаданими для електронних документів.

Необхідною передумовою становлення системи соціальних комунікацій $є$ комунікаційний процес. Нині електронні комунікації створюють умови для вчасного опрацювання й об'єднання діловодних процесів підрозділів бібліотеки в єдину систему інформаційного забезпечення управління. Крім того, електронні комунікації володіють такими характеристиками, як: точність і несуперечність, оперативність, повнота, достовірність інформації та доступність ії користувачам тощо. Разом 3 тим, керівник зможе швидше перевірити відповідність кінцевого результату поставленому завданню, що значно підвищить якість роботи 
як окремого співробітника, так і окремого підрозділу, а в підсумку й бібліотеки загалом.

Відзначимо, що на сьогодні формування системи ефективних комунікацій й удосконалення документно-комунікаційних процесів управління бібліотекою зумовить створення якісного комунікативного простору, необхідного для реалізації іiі стратегічних напрямів розвитку, зокрема:

- поліпшення організаційної структури управління;

- забезпечення чітких потреб керівництва в інформації всіх рівнів управління й упорядкування потоків інформації відповідно до цих потреб;

- передача інформаційного повідомлення одночасно кількома каналами зв'язку (усна, документна й електронна форми);

- надання достатньої уваги щодо процесів обміну інформацією (обговорення, звіти, контроль);

- організація системи зворотних зв'язків (збір пропозицій, досвід, ротація кадрів);

- у упорядкування структури комунікаційного процесу шляхом усунення надмірних і дублюючих операцій;

- застосування сучасних інформаційних технологій й удосконалення електронного документообігу;

- забезпечення підвищення компетентностей управлінського персоналу.

Отже, комунікаційна основа управління бібліотекою базується на функціонуванні підсистем документно-комунікаційного середовища, особливостями якого $\epsilon: 1)$ комунікація $\epsilon$ однією з важливих умов розвитку й існування бібліотеки; 2) комунікації розкривають стан внутрішнього середовища бібліотеки, а саме: мету, структуру, технологію, завдання і персонал, шляхом забезпечення функціонування і взаємодії працівників установи з іiі структурними підрозділами, а також структурних підрозділів між собою; 3) комунікація здій- снює взаємодію із зовнішнім середовищем бібліотеки, а саме: система законодавчих i нормативно-правових актів, що визначають цілі, завдання й основні параметри організації діяльності бібліотеки, розкриваючи рівень і якість прийняття управлінських рішень; система маркетингових комунікацій переслідує мету поліпшення збуту продуктів і послуг бібліотеки та залучення користувачів, активно i цілеспрямовано займається рекламою, пропагандою бібліотечних фондів, кращих видань, що важливо усвідомлювати в умовах конкуренції.

На нашу думку, на специфіку документноінформаційних комунікацій управління бібліотекою впливає характер комунікаційних зв'язків іiї зовнішнього та внутрішнього середовищ, що фіксують у певних документах. Від надійної комунікації й взаєморозуміння між іiі учасниками залежить наявність ефективної комунікації в діяльності бібліотеки, що $є$ однією з важливих умов успішного іiї функціонування.

Висновки. Комунікація, яка побудована на обміні між двома або більше учасниками комунікаційного процесу, у результаті створення, зберігання й розповсюдження документів і є документною комунікацією. Таким чином, документна комунікація в управлінні бібліотекою - це система, що охоплює документообіг установи, засоби їх доведення до користувача, власне бібліотеки як документноінформаційні інституції, зокрема керівники та певні працівники як учасники комунікаційного процесу (комунікант $\rightarrow$ реципієнт), i зв'язок, який забезпечує процес передачі інформації у зворотному напрямі (реципі$\epsilon$ нт $\rightarrow$ комунікант). Водночас удосконалення цих процесів сприятиме формуванню якісного внутрішнього й зовнішнього документнокомунікаційного середовища, необхідного для реалізації стратегічних напрямів розвитку бібліотеки. 


\section{Список використаних джерел}

1. Вилегжаніна М. В. Нормативно-правові акти в комунікаційному середовищі сучасної України : автореф. дис. ... канд. наук із соц. комунікацій : 27.00.02 / М. В. Вилегжаніна ; НАКККіМ. Київ, 2011. $18 \mathrm{c}$.

2. Горовий В. М. Соціальні інформаційні комунікації, їх наповнення і ресурс : монографія. Київ, 2010. 356 с.

3. Гутброд Г., Беляков О. Успішна комунікація в бізнесі та освіті : навч. посібник. Київ : ВПЦ «Київський ун-т», 2006. 207 с.

4. Добко Т. В. Довідково-бібліографічна діяльність бібліотек НАН України: трансформація змісту, форми і методів під впливом зміни інформаційно-комунікаційного середовища : автореф. дис. ... д-ра наук із соц. комунікацій : 27.00.03. ; НБУВ. Київ, 2013. 33 с.

5. Добровольська В. В. Теоретико-методологічні засади дослідження комунікаційного середовища документознавства // Бібл. вісн. 2014. № 1. С. 26-31.

6. Збанацька О. М. Документ у реаліях сьогодення // Бібл. планета, 2016. № 3. С. 23-27.

7. Кушнаренко Н. М. Документоведение : учебник для студ. вузов культуры. 6-е изд., стереотип. Киев : Знання, 2005. 459 с. (Сер. «Высшее образование XXI века»).

8. Ломачинська I. М. Документально-інформаційні комунікації в системі соціальних комунікацій : навч. посіб. для дистанційного навчання / за наук. ред. Т. Г. Горбаченко. Київ : Ун-т «Україна», 2008. $301 \mathrm{c}$.

9. Палеха І. Ю., Мурейко Н. В. Роль документально-інформативних комунікацій у розвитку суспільства // Бібліотекознавство. Документознавство. Інформологія. 2014. № 4. С. 79-85.

10. Різун В. В. Начерки до методології досліджень соціальних комунікацій // Інститут журналістики. Київ, 2011. URL: http: // journlib.univ.kiev.ua/Nacherky_do_metodologiyi.pdf.

11. Соляник А. А. Документні потоки та масиви : навч. посібник для вищ. навч. закл. культури і мистецтв. Харків : ХДАК, 2000. 112 с.

12. Социальные коммуникации : теория, методология, деятельность : словарь-справочник / авт.сост. : В. А. Ильганаева. Харьков : Гор. тип., 2009. 391 с.

Швецова-Водка Г. М. Документальна комунікація як об'єкт загальної теорії документології. URL: http://nbuv.gov.ua/UJRN/bdi_2010_2_9.

Швецова-Водка Г. М. Документознавство : словник-довідник термінів і понять : навч. посібник. 2-ге вид., стер. Київ : Знання, 2012. 319 с.

\section{References}

1. Vylezhanina, M. V. (2011). Legal Regulatory Acts in the Communication Environment of Modern Ukraine. Extended abstract of candidate's thesis. Kyiv: NAKKKiM [in Ukrainian].

2. Horovyi, V. M. (2010). Social Information Communications, their Content and Resource. Kyiv [in Ukrainian].

3. Gutbrod, G. \& Belyakov, O. (2006). Successful Communication in Business and Education. Kyiv: Kyivskyi Universytet [in Ukrainian].

4. Dobko, T. V. (2013). Reference and Bibliographic Activity of NAS Libraries: Transformation of Content, Form and Methods under the Influence of Changing Information and Communication Environment. Extended abstract of doctor's thesis. Kyiv: NBUV [in Ukrainian].

5. Dobrovolska, V. V. (2014). Theoretical and Methodological Principles of the Study of the Communication Environment of Document Science. Bibliotechnyi visnyk, 1, 26-31 [in Ukrainian].

6. Zbanatska, O. M. (2016). The Document in the Realities of the Present // Bibliographichna Planeta, 3, 23-27 [In Ukrainian].

7. Kushnarenko, N. M. (6th ed.). (2005). Documentation. Kyiv: Znannia, [in Russian].

8. Lomachinska, I. M. (2008). Documentary-Informational Communications in the System of Social Communications. T. G. Gorbachenko (ed.). Kyiv: Universytet Ukraina [in Ukrainian].

9. $\quad$ Palekha, I. Y. \& Mureiko, N. V. (2014). The Role of Documentary-Informative Communications in the Development of the Society. Bibliotekoznavstvo. Dokumentoznavstvo. Informologia, 4. 79-85 [in Ukrainian].

10. Rizun, V. V. (2011). Essays on the Methodology of the Social Communications Researches. Institute of Journalism. Kyiv. Retrieved from http: // journlib.univ.kiev.ua /Nacherky_do_metodologiyi.pdf [in Ukrainian].

11. Solyanik, A. A. (2005). Documentation System of Documentary Funds: Patterns of Development. 